\title{
Distribution and Diversity of Freshwater Crabs (Decapoda: Brachyura: Potamidae, Gecarcinucidae) in Iranian Inland Waters
}

\author{
Ardavan Farhadi (D), Muzaffer Mustafa Harlığlu (i)
}

Cite this article as: Farhadi, A., Harlığlu, M.M. (2018). Distribution and Diversity of Freshwater Crabs (Decapoda: Brachyura: Potamidae, Gecarcinucidae) in Iranian Inland Waters. Aquatic Sciences and Engineering, 33(4): 110-116.

Firat University, Fisheries Faculty, 23119, Elazığ, Turkey

\section{Submitted:}

08.05.2018

Accepted:

27.07.2018

Available Online Date: 15.10.2018

Correspondence:

Ardavan Farhadi

E-mail:

Farhadi219@yahoo.com

CCopyright 2018 by Aquatic

Sciences and Engineering

Available online at

ase.istanbul.edu.tr

\begin{abstract}
This article reviews the current knowledge of primary freshwater crabs (Decapoda, Brachyura) in Iranian inland waters, with the purpose of classifying the exact number of species, the threat status, and their distribution and diversity. Previous studies have reported that Iranian inland waters have eight freshwater crab species and there was no accurate information on the distribution of freshwater crab species in Iran. This review article describes that an additional six freshwater crab species, Potamon gedrosianum, P. magnum, P. mesopotamicum, P. ilam, Sodhiana blanfordi, and $S$. iranica, are also present in Iran. Therefore, there are 14 freshwater crab species currently known in Iran, which belong to two families (Gecarcinucidae and Potamidae). The genus Potamon is represented by 11 species, and the genus Sodhiana is represented by 3 species (found in south and south east of Iran). In addition, this review presents a distribution map and the possible threats for each species.
\end{abstract}

Keywords: Brachyura, decapoda, freshwater crabs, distribution, Iran

\section{INTRODUCTION}

Primary freshwater crabs (Yeo et al., 2008, 2012) include more than 1,476 species worldwide and occupy 20 percent of all the brachyurans (Yeo et al., 2008; Cumberlidge et al., 2009). They are composed of five families; Pseudothelphusidae Ortmann, 1893 (Neotropics; Wehrtmann et al., 2010) and Trichodactylidae H. Milne Edwards, 1853 (Mexico, Central and South America; Collins et al., 2006), Potamonautidae Bott, 1970 (Africa and Madagascar; Cumberlidge and Daniels, 2008), and, Potamidae Ortmann, 1896 (North Africa, southern Europe, Asia; Brandis et al., 2000), Gecarcinucidae Rathbun, 1904 (Seychelles, Asia; Shih and Ng, 2011),

Freshwater crabs live in both tropics and subtropics in most regions of the world (Yeo et al., 2008). They can be found in most freshwater ecosystems, from clear, quick-flowing rivers to moderate-flowing rivers, as well as in freshwa- ter swamps, stagnant ponds and rice fields, and even in tree hollows and leaf axils (Yeo et al., 2008; Cumberlidge et al., 2009).

However, some freshwater crab species, such as Potamon Savigny, 1816, are only present in freshwater habitats and are not able to live or survive for a long time in saline water, while other genus, such as Parathelphusa H. Milne Edwards, 1853 , is able to remain alive in saline water for a short time (Yeo et al., 2008). Terrestrial freshwater crab species can live far from continual freshwater sources; they are able to move among the forest floor litter or, sometimes, are even able to climb trees ( $\mathrm{Ng}, 1988 ; \mathrm{Ng}$ and Tay, 2001; Cumberlidge et al., 2005). Continual immersion in fresh water is not urgent for terrestrial freshwater crab species and they can receive water from food, drinking dew or casual water; they can obtain water by capillary or osmotic uptake from moist substrata (Yeo et al., 2008). 
Freshwater crabs play important ecological roles especially in tropical regions (Dobson et al., 2007a,b). In addition, they are medically important as a threat to human health (i.e. as intermediate hosts of paragonimiasis in Asia, Africa, and the Neotropics) (Maleewong, 2003; Blair et al., 2008) and as a source of medical and pharmaceutical materials (i.e. chitin and chitosan) (Rinaudo, 2006). Freshwater crabs are not used only as a food source, but are also used as food additives and fertilizers, especially crab processing residues are used as feeding additive (Bilgin and Fidanbaş, 2011). Therefore, in addition to the importance of marine crabs, there has also been an increase in the value of freshwater crabs in recent years on a global scale (Yeo et al., 2008).

Two different families of freshwater crabs are present in Iran i.e., Gecarcinucidae and Potamidae (Pretzmann, 1962). Many Potamid species moved to several geographically isolated areas, and adapted to dominant environments (Keikhosravi and Schubart, 2014a). These freshwater crabs in the Eurasian area have extended from the Mediterranean region to the east-Himalaya (Klaus et al., 2011; Gherardi, 2007). The genus Potamon in Iran includes three sub-genera; Pontipotamon Pretzmann, 1962 (Ashourdan et al., 2014), Centropotamon Pretzmann, 1962 (Nasrollahzadeh et al., 2011), and Orientopotamon Pretzmann, 1962 (Brandis et al., 2000).

The subgenus Pontipotamon is dominant in the south and the south-west Caspian region, the subgenus Centropotamon is dominant in the south Caspian Sea region in the center and south of Iran, while the subgenus Orientopotamon has been reported from the east Caspian Sea and southeast Iran (Pretzmann, 1962).

Brandis et al. (2000) and Sharifian et al. (2014), examined seven Potamon species (Potamon bilobatum Brandis, Storch and Türkay, 2000, P. elbursi Pretzmann, 1976, P. ibericum (Bieberstein, 1809), P. persicum Pretzmann, 1962, P. ruttneri Pretzmann, 1962, P. strouhali Pretzmann, 1962, P. transcaspicum Pretzmann, 1962) and one gecarcinucid species (Sodhiana rokitanskyi (Pretzmann, 1971)) from Iran. Recent active studies bring the number of Iranian species to 14 (Sharifian et al., 2014; Keikhosravi and Schubart, 2014a,b; Keikhosravi et al., 2016; Sharifian et al., 2017). The

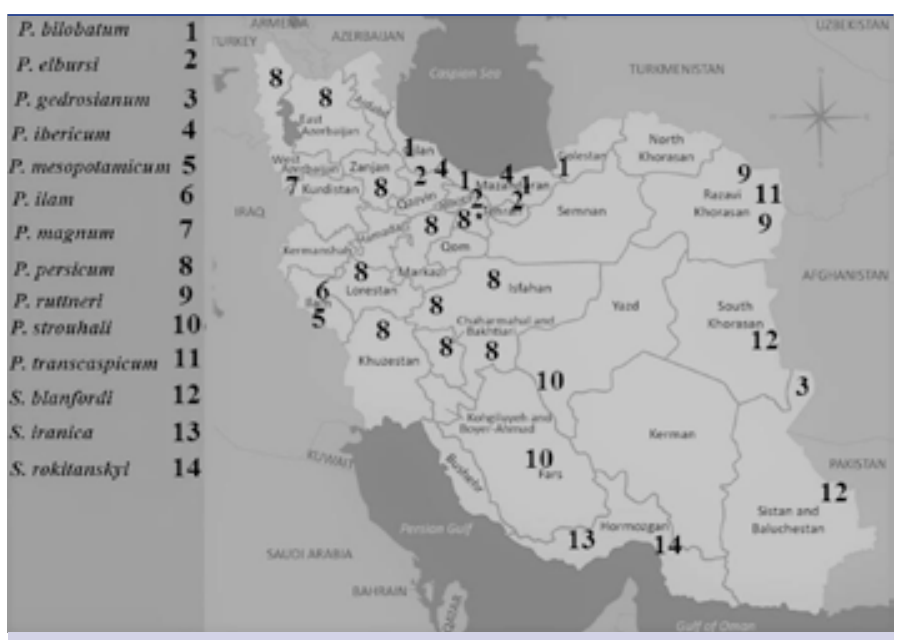

Figure 1. Distribution of freshwater crab species in Iran genus Potamon is represented by 11 species in Iranian inland waters; P. bilobatum; P. elbursi; P. gedrosianum Alcock, 1909; P. ibericum; P. mesopotamicum Brandis, Storch and Türkay, 1998; $P$. ilam Keikhosravi and Schubart, 2014; P. (Centropotamon) magnum Pretzmann, 1962; P. persicum; P. ruttneri; $P$. strouhali and $P$. transcaspicum. In addition, three species of the genus Sodhiana are found in Iranian inland waters; Sodhiana blanfordi (Alcock, 1909); Sodhiana iranica Sharifian, Kamrani and Sharifian, 2014 and S. rokitanskyi. Figure 1 shows the distribution of freshwater crab species in Iran.

This study is aimed to consolidate and update the distribution and biodiversity of freshwater crabs in Iranian inland waters.

\section{Taxonomy}

\section{Family Potamidae Ortmann, 1896}

\section{Potamon bilobatum Brandis, Storch and Türkay, 2000}

Potamon bilobatum Cumberlidge, 2008a (type locality: Mazandaran and Gilan provinces, Iran); Nasrollahzadeh et al., 2011: 280.

Potamon (Pontipotamon) bilobatum Brandis, Storch and Türkay, 2000: 26-28 (type locality: Mazandaran, Iran).

Distribution in Iran. This species was reported only in the north of Iran from the Elburs Mountains, in Gilan (Rasht, Kelachay), Mazandaran (Chalus, Tonekabon) and Golestan Provinces (Gorgan) (Cumberlidge, 2008a; Nasrollahzadeh et al., 2011).

Remarks. This species is listed as Least Concern in International Union for Conservation of Nature (IUCN) red list of threatened species. Since there is no record showing reduction in the extent and quality of its habitat. This species has been identified in three provinces in Iran (Cumberlidge, 2008a; Nasrollahzadeh et al., 2011). This species was found in Lakan stream when the water temperature, salinity, hardness, and $\mathrm{pH}$ was $16-18^{\circ} \mathrm{C}, 330$ $430 \mathrm{mg} / \mathrm{l}, 12-16^{\circ} \mathrm{d}$, and 7-7.7 respectively (Nasrollahzadeh et al., 2011).

\section{Potamon elbursi Pretzmann, 1976}

Potamon elbursi Pretzmann, 1976b: (type locality: northern Iran); Keikhosravi and Schubart, 2014a: (Namak Lake and south Caspian Sea drainages).

Distribution in Iran. Keikhosravi and Schubart (2014a) redescribed Potamon elbursi, proving its occurrence as a native species of northern Iran. P. elbursi is distributed from the north to the central and southern slopes of the western Alborz Mountains (the north of Tehran and Qazvin), and from the south to the sources of two drainage systems (northeast of Tehran), Namak Lake and south Caspian Sea drainages. Only at one point does the distribution extend northward through the Alborz Mountains (Sefidrud valley), reaching the Caspian Sea (Keikhosravi and Schubart 2014a; Keikhosravi et al., 2015).

Remarks. P. elbursi is distinguished from P. persicum by the morphology of the first gonopods in males (Keikhosravi and Schubart 2014a). Consistent and marked genetic divergence was also recognized in the mitochondrial 16S rRNA and cytochrome oxidase subunit I genes (Keikhosravi and Schubart 2014a). 


\section{Potamon gedrosianum Alcock, 1909}

Potamon gedrosianum Alcock, 1909 (type locality: Pishin Valley, Baluchistan, Pakistan); Quddusi, et al., 2005 (Sindh, Punjab and Baluchistan Provinces, Pakistan); Keikhosravi et al. 2016 (Zabol, southeast of Iran).

Potamon gedrosianum waziristanis Pretzmann, 1965: 297 (Kabul, Afghanistan).

Potamon gedrosianum torbenwolffi Bott, 1967 (type locality: west of Afghanistan.).

Distribution in Iran. Potamon gedrosianum is found in Afghanistan, northeastern Iran (Keikhosravi et al., 2016), northwestern Pakistan, western India and the western tributaries of the Indus River (Cumberlidge, 2008b). For the first time, in 2016, P. gedrosianum has been reported in Iran by Keikhosravi et al. (2016) in Zabol (southeast of Iran).

Remarks. Alcock (1909) reported a new subspecies of Potamon fluviatile (i.e. P. f. gedrosianum) from Pakistan. Recently, Brandis et al. (2000) synonymized this newer subspecies and ranked it at species level. P. gedrosianum and P. ruttneri have very similar morphology. Also, gonopod morphology is constant or has very limited variation at intraspecific level in both species (Brandis et al., 2000). However, P. gedrosianum and P. ruttneri are distinguished by the structure of the first male gonopod (G1) and carapace features (Brandis et al., 2000).

Cumberlidge (2008b) listed P. gedrosianum as Least Concern in IUCN red list of threatened species in view of its wide distribution in four countries, tolerance of a degree of habitat modification, presumed large population, and because it is unlikely to be declining fast enough to qualify for listing in a more threatened category (Cumberlidge, 2008b).

\section{Potamon ibericum (Bieberstein, 1809)}

Cancer ibericum Bieberstein, 1809: 3-5 (type locality: Mazandaran, North of Iran).

Potamon ibericum Scombathy, 1916 (type locality: near Yerevan, Armenia.); Charmantier, 1992 (southern France).

Potamon (Pontipotamon) ibericum Bieberstein, 1808: (Mazandaran, North of Iran).

Potamon (Pontipotamon) ibericum tauricum natio bithyniensis Pretzmann, 1983: 281-300 (Turkey)

Potamon (Pontipotamon) ibericum tauricum natio cappadociensis Pretzmann 1983 (Cappadocia, central Turkey).

Potamon (Pontipotamon) ibericum tauricum natio troijensis Pretzmann (Thassos, Greek island).

Potamon albanicum Starobogatov and Vassilenko, 1979: 1795, (type locality: Cyprus).

Potamon ibericum meandris Pretzmann, 1963 (type locality: Shahpasant, Iran).
Thelphusa fluviatilis taurica Czerniavsky, 1884 (type locality: Chios, Greek islands). Pretzmann, 1976b (Rasht, Iran). Pretzmann, 1963: 376 (Trabzon, Turkey; Samsun, Turkey).

Distribution in Iran. Potamon ibericum occurs in a wide and highly fragmented regions. P. ibericum present from the Danube River to the Black Sea and the Caspian. P. ibericum is found in Bulgaria, Ukraine, Crimea, Georgia, Armenia, and Azerbaijan. P. ibericum is a species also present in the region to south of the Caspian Sea region in Turkmenistan (Cumberlidge, 2008c) and Iran. In Iran, P. ibericum is present in the north of Iran from the Elburs Mountains, in the Sefidrud opening connected to the Caspian Sea, and in the coastal region of the Caspian Sea, Gilan Province (Langerud, Rudsar, Kelachay) and Mazandaran Provinces (Chalus) (Ashourdan et al., 2014; Parvizi et al., 2017).

Remarks. P. ibericum has a wide distribution and the relatively high number of localities and records. P. ibericum is assessed here as Near Threatened (NT) in IUCN red list of threatened species. Because it is possible that populations of $P$. ibericum in parts of its range might be in danger of extirpation in the future, especially those on islands or near centers of human population on the mainland (Cumberlidge, 2008c).

\section{Potamon mesopotamicum Brandis, Storch and Türkay, 1998}

Potamon mesopotamicum Brandis, Storch and Türkay, 1998 (type locality: Khabur River, Syria); Naser, 2009 (southern regions of Iraq); Keikhosravi and Schubart, 2014b: 119 (Ilam, west of Iran).

Distribution in Iran. Potamon mesopotamicum is found at the Turkey-Syria border (Sanliurfa Province), Syria (sources of the Khabur River in Ras al-Ain; Nar al-Khabur) (Brandis et al., 1998; Esser and Cumberlidgea, 2008a) and recently Naser (2009) extended the range of $P$. mesopotamicum to southern regions of Iraq, over $400 \mathrm{~km}$ to the southeast. In the Al-Huwaizah marshes, P. mesopotamicum lives in areas of still, shallow water, on mud or among submerged aquatic plants (Ceratophyllum sp.). In addition, recently $P$. mesopotamicum has been reported in the west of Iran (Ilam) on the Iran-Iraq border (Keikhosravi and Schubart, 2014b).

Remarks. Potential threats for the survival of $P$. mesopotamicum and other aquatic organisms in these marshes include the application of pesticides by fishermen and illegal overfishing (Al-Helfi, 2005).

\section{Potamon ilam Keikhosravi and Schubart, 2014}

Potamon ilam Keikhosravi and Schubart, 2014b (type locality: Ilam, south west of Iran).

Distribution in Iran. Potamon ilam is found in most of the rivers in llam (south west Iran) that drain into the Tigris River (except for some rivers in the eastern part), but it is not found in the Tigris River itself, where P. mesopotamicum, P. persicum, and P. magnum occur (Keikhosravi and Schubart, 2014b).

Remarks. Keikhosravi and Schubart (2014b) suggested that Potamon ilam is distinguished from P. persicum and P. mesopotamicum by the shape of the first gonopod and carapace characters. In addition, other differences between these taxa are evi- 
dent from nuclear 28S rRNA and mitochondrial 16S rRNA gene sequences (Keikhosravi and Schubart, 2014b).

\section{Potamon magnum Pretzmann, 1962}

Potamon (Centropotamon) magnum Pretzmann, 1962 (type locality: eastern Turkey); Alsalami and Rahma, 2015 (Al-Kufa river, Iraq); Luay and Jawair, 2013 (Greater Zab river Kurdistan RegionIraq).

Distribution in Iran. Potamon magnum occurs mostly in eastern Turkey in the upper reaches of the Euphrates and Tigris Rivers, in northern Syria, northeast of Iraq, in western Armenia and western Iran (Baneh) (Cumberlidge, 2008d; Ali and Latef, 2017).

Remarks. Cumberlidge (2008d) assessed Potamon magnum as Least Concern in IUCN red list of threatened species based on its relatively wide distribution (EOO 145,000 $\mathrm{km}^{2}$ ) and the relatively high number of localities and records in five countries. Potamon magnum populations may nevertheless be under threat from rapid anthropogenic changes affecting their habitat, such as water diversion and pollution. No information exists on the population dynamic or density of $P$. magnum (Cumberlidge, 2008d). Alsalami and Rahma (2015) showed that the most important factors that affect presence of $P$. magnum is the water temperature and salinity. The highest density reached (32.89) individual / $\mathrm{M}^{\circ}$ at a temperature of $20^{\circ} \mathrm{C}$ during April, no crab observed was observed during January and February when the water temperature was $14.5^{\circ} \mathrm{C}$ and $14.1^{\circ} \mathrm{C}$ respectively (Alsalami and Rahma, 2015).

\section{Potamon persicum Pretzmann, 1962}

Potamon persicum Pretzmann, 1962: 205 (type locality: Isfahan, Iran); Khatami, 2002 (type locality: Jajrood River, Tehran, Iran); Ardalan et al., 2011: 179 (Elburs Mountains); Keikhosravi and Schubart, 2014a: 116 (Kohkiluyeh buyerahmad province, Chaharmahal Bakhtiari province Esfahan, Khuzestan province, Iran). Keikhosravi and Schubart, 2014b: 117 (Khuzestan province Tehran province, Iran).

Potamon (Centropotamon) hueceste armenicum Pretzmann, 1983 (type locality: Makoom Northwest of Iran).

Potamon (Centropotamon) magnum elbrusi Pretzmann, 1962 (type locality: Rasht, Iran).

Potamon (Centropotamon) magnum vangoelium Pretzmann, 1976a (Mazandaran, Iran part).

Potamon (Centropotamon) persicum Pretzmann, 1962 (type locality: Isfahan, Iran).

Potamon (Centropotamon) persicum kermanshahi Pretzmann, 1976b (type locality: Kermanshah, West of Iran)

Potamon magnum armenicum Pretzmann, 1962 (type locality: Northwest of Iran); Pretzmann, 1963: 375.

Distribution in Iran. Potamon persicum is found in Iran (Azarbayejane Gharbi, Azarbayejane Sharqi, Gilan, Markazi, Hamadan, Bakhtaran, Lorestan, Esfahan Provinces), Turkey, Iraq and in Armenia. Also, this species is found in the Tigris-Euphrates river systems and in the region from Lake Van to the Elburs Mountains and in the region south of Esfahan in Iran (Cumberildge, 2008e; Ardalan et al., 2011; Keikhosravi and Schubart 2014a,b).

Remarks. Cumberildge (2008e) assessed Potamon persicum as Least Concern in IUCN red list of threatened species based on its wide distribution (E00 1 million $\mathrm{km}^{2}$ ) and the high number of localities and records from Iran, Turkey, Iraq and Armenia (Cumberildge, 2008e).

\section{Potamon ruttneri Pretzmann, 1962}

Potamon ruttneri Pretzmann, 1962 (type locality: Amirabad, Tabas, Iran); Keikhosravi et al., 2016 (Khorasan Razavi, Iran and Herat, Afghanistan).

Potamon gedrosianum lindbergi Pretzmann, 1966: 297 (type locality: west of Afghanistan)

Potamon gedrosianum linberglundi Bott, 1967 (type locality: northwestern Afghanistan).

Distribution in Iran. P. ruttneri is found in northeastern Iran between Mashhad and Birjand. It is also found in northwestern Afghanistan (Herat and Oruzgan Provinces) (Cumberlidge, 2008f; Keikhosravi et al., 2016).

Remarks. Potamon ruttneri is listed as Least Concern in IUCN red list of threatened species because of its wide distribution in Iran and Afghanistan (Cumberlidge, 2008f).

\section{Potamon strouhali Pretzmann, 1962}

Potamon strouhali Pretzmann, 1962: 205 page (type locality: Yazd, Iran); Farzanpay and Pretzmann, 1974 (type locality: southeast Iran).

Potamon (Orientopotamon) eiselti Pretzmann, 1976a (type locality: Niriz, Iran)

Potamon (Orientopotamon) strouhali Pretzmann, 1962; 205 (type locality: Yazd, Iran): Pretzmann, 1963: 379.

Potamon strouhali shurium Pretzmann, $1976 b$ (type locality: Shiraz, Iran).

Distribution in Iran. Potamon strouhali is found in southeast Iran (Yazd and Shiraz) up to the Afghan border region.

Remarks. P. strouhali is listed as Least Concern in IUCN red list of threatened species in (Cumberlidge, 2008g).

\section{Potamon transcaspicum Pretzmann, 1962}

Potamon transcaspicum Pretzmann, 1962: 205 (type locality: northeast Iran); Keikhosravi et al., 2016 (type locality: Zabul, Afghanistan and Zardkoohi, Sabzevar, Iran).

Potamon (Orientopotamon) transcaspicum Pretzmann, 1962 (Bojnourd, Iran).

Potamon (Orientopotamon) turkmenicum Pretzmann, 1962 (Bojnourd, Iran); Pretzmann, 1976b.

Potamon (Potamon) zarudnyi Starobogatov and Vassilenko, 1979: 1790-1801 (type locality: Cyprus). 
Distribution in Iran. Potamon transcaspicum is found in Ukraine (Crimea), Turkmenistan and north east of Iran Khorasan Province (Sabzevar) (Cumberlidge, 2008h; Keikhosravi et al., 2016).

Remarks. P. transcaspicum is listed as Least Concern in IUCN red list of threatened species because of its wide distribution (Cumberlidge, 2008h).

\section{Family Gecarcinucidae Rathbun, 1904}

\section{Sodhiana blanfordi (Alcock, 1909)}

Paratelphusa (Paratelphusa) blanfordi Alcock, 1909: 375 (Type locality: Baluchistan, Pakistan); Pretzmann, 1963: 379.

Sartoriana blanfordi Bott 1970 (Type locality: Southern Iran); Cumberlidge, 2008i (Type locality: Baluchistan, Pakistan); Kamrani et al., 2009 (Type locality: Southern Iran).

Sodhiana blanfordi Yeo and Ng, 2012 (Baluchistan, Pakistan); Sharifian et al., 2014 (south east of Iran).

Distribution in Iran. It is found in the south east of Iran, Sistan and Baluchestan Province and Hormozgan Province (Bastak), Pakistan and Afghanistan (Cumberlidge, 2008i; Sharifian et al., 2014).

Remarks. It is listed as Least Concern in IUCN red list of threatened species. Sodhiana blanfordi extent of occurrence is in area less than $2,000 \mathrm{~km}^{2}$ and all individuals occur in fewer than five localities (Cumberlidge, 2008i).

\section{Sodhiana iranica Sharifian, Kamrani and Sharifian, 2014}

Sodhiana iranica Sharifian, Kamrani and Sharifian, 2014 (type locality: Bastak region in the south of Iran).

Distribution in Iran. This species is a gecarcinucid crab from the Bastak region in the south of Iran (Bandar Abbas), only recently reported to be a new species (Sharifian et al., 2014). It inhabits a freshwater spring located in a semi-mountainous area in Iran (Eellod area), covered by dense stands of common reeds and salt cedar trees in the periphery, with algae mats on the bottom (Sharifian et al., 2014).

Remarks. S. iranica is easily separated from S. rokitanskyi by having the epigastric cristae lower and less pronounced, and coming close to or almost in contact with the postorbital cristae, whereas they are more prominent in S. rokitanskyi (Sharifian et al., 2014).

Sharifian et al. (2017) studied population dynamic of S. iranica. No significant differences were detected among mean male and female carapace widths and the sex ratio (male:female) was 1:0.7 in S. iranica. The maximum life span of $S$. iranica is evaluated to be 1.1- 4.9 years (Sharifian et al., 2017). In addition, Sharifian et al. (2017) suggested that suitable management is essential for conservation of $S$. iranica in the freshwater spring of the Eelood Area (near Bandar Abbas).

\section{Sodhiana rokitanskyi (Pretzmann, 1971)}

Liotelphusa (Sartoriana) rokitanskyi Pretzmann, 1971 (type locality: Minab, Iran).
Sartoriana rokitanskyi Esser and Cumberlidge, 2008b: (type locality: Minab, Iran); Mirzadeh et al., 2011 (Hormozgan Province, Iran).

Sodhiana rokitanskyi Yeo and Ng, 2012 (south of Iran).

Distribution in Iran. Sodhiana rokitanskyi is only found in Iran. The type locality is the Minab River near Minab, east of Bandar Abbas, Geno and Rudan marshes, in Hormozgan Province, southern Iran (Esser and Cumberlidge, 2008b; Mirzadeh et al., 2011; Yeo and Ng, 2012). Kamrani et al. (2009) described the characteristics of the marsh crab, S. rokitanskyi. S. rokitanskyi belongs to the family Gecarcinucidae, which is related to true crabs.

Remarks. Yeo and Ng (2012) subsequently revised Sartoriana Bott, 1969, and transferred three species to a new genus, Sodhiana: S. blanfordi (Alcock, 1909), S. afghaniensis (Pretzmann, 1963), and S. rokitanskyi (Pretzmann, 1971).

There is not enough information about this species to make a thorough assessment of S. rokitanskyi. Therefore, S. rokitanskyi is listed as Data Deficient (Esser and Cumberlidge, 2008b).

\section{CONCLUSION}

Studies on freshwater crabs in Iranian inland waters are limited to species reorganization and their diversity. Further studies are required to investigate habitat requirements, population structure, disease, biology and ecology of Iranian freshwater crabs. In addition, further studies are needs to survey fisheries (i.e. evaluate maximum sustainable yield and economy benefits), aquaculture (i.e. assay possibility of successful aquaculture) and industry importance (i.e. chitin and chitosan levels) of freshwater crabs in Iran.

Conservation measures require a complete inventory of distribution and habitat requirements of freshwater crab species, evaluations of population levels and trends, and creation of protected areas. Fortunately, most of the freshwater crabs of Iran are listed as Least Concern in the IUCN Red List of Threatened Species.

Acknowledgments: We gratefully thank Prof. Julian D. Reynolds for his help in improving our manuscript.

Conflict of Interest: The authors have no conflicts of interest to declare.

\section{REFERENCES}

Ali, L.A.Q., Latef, B.A. (2017). A Study of Invertebrates Community in Lesser Zab River/Kurdistan Region-Iraq. ZANCO Journal of Pure and Applied Sciences 29, 54-64.

AL-Helfi, M.A.A. (2005). Insecticides impact in southern Iraqi marshes environment. Marina Mesopotamica 20, 81-89.

Alcock, A. (1909). Diagnosis of new species and varieties of freshwater crabs. Nos. 1-3. Records of the Indian Museum 3, 243-381.

Alsalami, A.H., Rahma, J.H. (2015). Newly record of the potamon magnum in the middle euphrates and the impact of environmental factors. International Journal of Biological Research and Development (IJBRD) 5, 1-4.

Ardalan, A.A., Mooraki, N., Sadeghi, M.S. (2011). Occurrence of Ophidonais serpentina in Potamon persicum from Jajrood River, Iran. Prevalence 6, 9-20. 
Ashourdan, Z., Asadian-narengi, S., Hosseini, S.G. (2014). Identification of Freshwater Flat Crab Species and Study of Its Sexual Maturation in Guilan, North of Iran. Anthesis Journal of Applied and Basic Sciences 2, 191-203.

Bieberstein, M.D.E. (1808). Notice sur queiques Insectes su Caucase. Moscou:Société impériale des naturalistes de Moscou, 2, 3-5.

Bieberstein, M.D. E. (1809). Instructions on queiques Insects knew Caucasus. Moscou :Société impériale des naturalistes de Moscou, 2, 3-5.

Bilgin, S. and Fidanbaş, Z. U. C. (2011). Nutritional properties of crab (Potamon potamios Olivier, 1804) in the lake of Eğirdir (Turkey). Pakistan Veterinary Journal, 31, 239-243.

Blair, D., Agatsuma, T., Wang, W. (2008). Chapter 3, Paragonimiasis. In: Murrell, K.D., Fried, B. (Eds.), Food-borne Parasitic Zoonoses. Springer, New York, pp.117-150.

Bott, R. (1967). Potamidae (Crustacea, Decapoda) aus Afghanistan, Westasien und dem Mittelmeerranum (Eine Revision der Untergattung Potamon s str.). Vidensk. Medd. dansk, nat. Foren, pp.7-43.

Bott, R. (1970). Die Süßwasserkrabben von Europa, Asien, Australienund ihre Stammgeschichte. Abhandlungen der Senckenbergischen Naturforschenden Gesellschaft, 526, 1-338.

Brandis, D., Storch, V., Türkay, M. (1998). The status of the freshwater crab populations of the Khabur River (Syria). Journal of Natural History 32, 1439-1445. [CrossRef]

Brandis, D., Storch, V., Turkay, M. (2000). Taxonomy and zoogeography of the freshwater crabs of Europe, North Africa, and the Middle East (Crustacea, Decapoda, Potamidae). Senckenbergiana Biologica 80, 5-56.

Charmantier, G. (1992): Occurrence of fresh-water crabs, genus Potamon, in southern France. Journal of Crustacean Biology 12, 620-626. [CrossRef]

Collins, P. A., Giri, F., Williner, V. (2006). March. Population dynamics of Trichodactylus borellianus (Crustacea Decapoda Brachyura) and interactions with the aquatic vegetation of the Paraná River (South America, Argentina). Annales de Limnologie-International Journal of Limnology 42, 19-25.

Cumberlidge, N., Fenolio, D. B., Walvoord, M. E., Stout, J. (2005). Treeclimbing crabs (Potamonautidae and Sesarmidae) from phytotelmic microhabitats in rainforest canopy in Madagascar. Journal of Crustacean Biology 25, 302-308. [CrossRef]

Cumberlidge, N, (2008a). Potamon bilobatum. The IUCN Red List of Threatened Species 2008:e.T134554A3976810.http://dx.doi. org/10.2305/IUCN.UK.2008.RLTS.T134554A3976810.en [CrossRef]

Cumberlidge, N. (2008b). Potamon gedrosianum. The IUCN Red List of Threatened Species 2008:e.T134284A3931900.http://dx.doi. org/10.2305/IUCN.UK.2008.RLTS.T134284A3931900.en [CrossRef]

Cumberlidge, N. (2008c). Potamon ibericum. The IUCN Red List of Threatened Species 2008: e.T134681A3997379.http://dx.doi.org/10.2305/ IUCN.UK.2008.RLTS.T134681A3997379.en [CrossRef]

Cumberlidge, N (2008d). Potamon magnum. The IUCN Red List of Threatened Species 2008:e.T135064A4048918.http://dx.doi.org/10.2305/ IUCN.UK.2008.RLTS.T135064A4048918.en [CrossRef]

Cumberildge, N (2008e). Potamon persicum. The IUCN Red List of Threatened Species 2008:e.T135016A4052882.http://dx.doi.org/10.2305/ IUCN.UK.2008.RLTS.T135016A4052882.en [CrossRef]

Cumberlidge, N (2008f). Potamon ruttneri. The IUCN Red List of Threatened Species 2008:e.T134482A3963856.http://dx.doi.org/10.2305/ IUCN.UK.2008.RLTS.T134482A3963856.en [CrossRef]

Cumberlidge, N. (2008g). Potamon strouhali. The IUCN Red List of Threatened Species 2008:e.T134812A4017346.http://dx.doi.org/10.2305/ IUCN.UK.2008.RLTS.T134812A4017346.en [CrossRef]

Cumberlidge, N. (2008h). Potamon transcaspicum. The IUCN Red List of Threatened Species 2008:e.T134009A3889835.http://dx.doi. org/10.2305/IUCN.UK.2008.RLTS.T134009A3889835.en [CrossRef]
Cumberlidge, N. (2008i). Sartoriana blanfordi.The IUCN Red List of Threatened Species 2008:e.T135033A4057787.http://dx.doi. org/10.2305/IUCN.UK.2008.RLTS.T135033A4057787.en [CrossRef]

Cumberlidge, N., Daniels, S.R. (2008). A conservation assessment of the freshwater crabs of southern Africa (Brachyura: Potamonautidae). African Journal of Ecology 46, 74-79. [CrossRef]

Cumberlidge, N., Ng, P.K., Yeo, D.C., Magalhães, C., Campos, M.R., Alvarez, F., Naruse, T., Daniels, S.R., Esser, L.J., Attipoe, F.Y., Clotilde-Ba, F.L. (2009). Freshwater crabs and the biodiversity crisis: importance, threats, status, and conservation challenges. Biological Conservation 142, 1665-1673. [CrossRef]

Czerniavsky, V. (1884): Materiala ad Zoographiam Ponticam comparatam. Fase. 11, Crustacea Decapoda Pontica Littoralia.

Dobson, M.K., Magana, A.M., Lancaster, J., Mathooko, J.M. (2007a). Aseasonality in the abundance and life history of an ecologically dominant freshwater crab in the Rift Valley, Kenya. Freshwater Biology 52, 215-225.

Dobson, M.K., Magana, A., Mathooko, J.M., Ndegwa, F.K. (2007b). Distribution and abundance of freshwater crabs (Potamonautes spp.) in rivers draining Mt. Kenya, East Africa. Fundamental and Applied Limnology 168, 271-279.

Esser, L. and Cumberlidge, N. (2008a). Potamon mesopotamicum. The IUCN Red List of Threatened Species 2008:e.T134133A3908104.http://dx.doi. org/10.2305/IUCN.UK.2008.RLTS.T134133A3908104.en [CrossRef]

Esser, L. and Cumberlidge, N. (2008b). Sartoriana rokitanskyi. The IUCN Red List of Threatened Species 2008:e.T134824A4019146.http://dx.doi. org/10.2305/IUCN.UK.2008.RLTS.T134824A4019146.en [CrossRef]

Farzanpay, R. and Pretzmann, G. (1974). Ergebnisse einiger Sammelreisen nach Vorderasien. 4. Teil: Skorpione aus Iran. Annalen des Naturhistorischen Museums in Wien, 78: 215-217.

Gherardi, F. (2007). Biological invasions in inland waters: an overview Biological invaders in inland waters: profiles, distribution, and threats. In: Gherardi F (ed) Invading nature: springer series in invasion ecology. Springer, Netherlands, p.734. [CrossRef]

Kamrani, E., Ng, P. K., Mirzadeh, M., Nakhodai, S. (2009). The marsh crab, Sartoriana rokitanskyi (Pretzmann, 1971)(Decapoda, Brachyura, Gecarcinucidae) from southern Iran. Zootaxa 2305, 24-32.

Keikhosravi, A. and Schubart, CD. (2014a). Revalidation and redescription of Potamon elbursi Pretzmann, 1976 (Brachyura, Potamidae) from Iran, based on morphology and genetics. Central European Journal of Biology 9, 114-123.

Keikhosravi, A. R. and Schubart, CD. (2014b). Description of a new freshwater crab species of the genus Potamon (Decapoda, Brachyura, Potamidae) from Iran, based on morphological and genetic characters. Advances in freshwater decapod systematics and biology. Crustaceana Monographs 19, 115-133.

Keikhosravi, A., Fratini, S., Schubart, C.D. (2015). Population genetic structure and demographic history of the freshwater crab Potamon elbursi (Brachyura: Potamidae) from the Alborz Mountains in northern Iran. Journal of Limnology 74, 512-518. [CrossRef]

Keikhosravi, A., Naderloo, R., Schubart, C. D. (2016). Morphological and molecular diversity in the freshwater crab Potamon ruttneri-P. gedrosianum species complex (Decapoda, Brachyura) indicate the need for taxonomic revision. Crustaceana 89, 129-139. [CrossRef]

Khatami, S. (2002). Identification and biology of freshwater crab (Potamon persicum) from Jajrood River. Ms. Thesis. Islamic Azad University, North Tehran Branch, pp.185.

Klaus, S., Yeo, D.C.J., Ahyong, S.T. (2011). Freshwater crab origins-laying Gondwana to rest. Zoologischer Anzeiger-A Journal of Comparative Zoology 250, 449-456. [CrossRef]

Luay A. A., Jawair, H. (2013). First record of Potamon magnum (Decapoda: Crustacea) in Greater Zab river Kurdistan region-Iraq. 4th international conference and workshop on basic and applied sciences. ICOWOBAS-RAFSS. 
Maleewong, W. (2003). Paragonimus species. In: Miliotis, M.D., Bier, J.W. (Eds.), International Handbook of Foodborne Pathogens. Marcel Dekker, Inc., New York, pp. 601-611. [CrossRef]

Mirzadeh, M., Kamrani, E., Shojae, F., Nakhodai, S., Dabbagh, A.R. (2011). Comparative Study of the Distribution the Marsh Crab, Sartoriana Rokitanskyi in Hormozgan Province. Journal of Life Science and Biomedicine 2, 92-94.

Naser, M.D. (2009). First Record of the Freshwater Crab, Potamon Mesopotamicum Brandis, Storch and Türkay, 1998 (Decapoda, Brachyura, Potamidae) from the Al-Huwaizah Marshes, Iraq. Crustaceana, 82, 1599-1602. [CrossRef]

Nasrollahzadeh, A., Noveirian, H. A., Soutohian, F. (2011). First report on freshwater crab species (Potamon bilobatum) in the altitudes of Guilan (Lakan area). Caspian Journal of Environmental Sciences 9, 279-283.

Ng, P.K.L. (1988). The Freshwater Crabs of Peninsular Malaysia and Singapore. Department of Zoology, National University of Singapore, Shinglee Press, Singapore, i-viii, 1-156, Figs. 1-63, 4 colour plates.

Ng, P.K.L., Tay, F.W.M. (2001). The freshwater crabs of Sri Lanka (Decapoda: Brachyura: Paratelphusidae). Zeylanica 6, 113-199.

Parvizi, E., Naderloo, R., Keikhosravi, A., Schubart, C. D. (2017). Life history traits and patterns of sexual dimorphism in the freshwater crab Potamon ibericum (Bieberstein, 1809)(Decapoda: Brachyura: Potamidae) from the western Alborz Mountains, Iran. The Journal of Crustacean Biology 37, 323-331. [CrossRef]

Pretzmann, G. (1962). Die mediterranen und vorderasiatischen Süßwasserkrabben (Potamoniden), Naturhistorisches Museum Wien, 205-240.

Pretzmann, G. (1963). Weiterer Bericht über die mediterranen und vorderasiatischen Potamoniden. Annalen des Naturhistorischen Museums in Wien, pp.373-380.

Pretzmann, G. (1965). Potamoniden (Crustacea Brachyura) aus Afghanistan. Annalen des Naturhistorischen Museums in Wien, pp.297-298.

Pretzmann, G. (1966). Die mediterranen und vorderasiatischen Potamoniden der naturhistorischen Museen in Paris, Turin, Kopenhagen und Washington. Annalen des Naturhistorischen Museums in Wien, pp.217-232.

Pretzmann, G. (1971). Ergebnisse einiger Sammelreisen nach Vorderasien: I. Teil: Zwei neue Unterarten von Süßwasserkrabben. Annalen des Naturhistorischen Museums in Wien 75, pp.473-475.

Pretzmann, G. (1976a). Ergebnisse einiger Sammelreisen nach Vorderasien 5. Weitere neue Süßwasserkrabben. Museums in Wien 80, 453-465.
Pretzmann, G. (1976b). Ergebnisse einiger Sammelreisen nach Vorderasien 6. Die Süßwasserkrabben Persiens. Annalen des Naturhistorischen Museums in Wien 80, pp.457-498.

Pretzmann, G. (1983). Ergebnisse einiger Sammelreisen nach Vorderasien. 7. Die Süßwasserkrabben der Türkei. Annalen des Naturhistorischen Museums in Wien. Serie B für Botanik und Zoologie pp.281300.

Quddusi, B. K., Khurshid, M., Parveen, N. (2005). Records of non-marine brachyuran crab species of Pakistan including a note on their ecology and description of juveniles of sartoriana blanfordi. Proceedings of Pakistan Congress of Zoology 25, 73-98.

Rinaudo, M. (2006). Chitin and chitosan: properties and applications. Progress in polymer science 31, 603-632. [CrossRef]

Scombathy, K. (1916). Die tertiären Formen der Gattung Potamon (Telphusa) und ihre paläarktischen Nachkommen. - Annales historiconaturales Musei Nationalis Hungarici 14: 381-421, Taf. 3, Abb. 1-9. Budapest 1916.

Sharifian, S., Kamrani, E., Sharifian, S. (2014). A new species of freshwater crab of the genus Sodhiana (Decapoda: Brachyura: Gecarcinucidae) from southern Iran. Zootaxa 3878, 485-490. [CrossRef]

Sharifian, S., Kamrani, E., Safaie, M., Sharifian, S. (2017). Population structure and growth of freshwater crab Sodhiana iranica from the south of Iran. Fundamental and Applied Limnology/Archiv für Hydrobiologie 189, 341-349. [CrossRef]

Shih, H. T., and Ng, P. K. L. (2011). Diversity and biogeography of freshwater crabs (Crustacea: Brachyura: Potamidae, Gecarcinucidae) from East Asia. Systematics and Biodiversity, 9: 1-16.

Starobogatov, J., Vassilenko, S (1979). Zur Systematik der Süßwasserkrabben der Familie Potamidae (Crustacea Decapoda, Brachyura) des Mittelmeergebietes und Vorderasiens. Zool. I. Leningrad 58, 17901801.

Wehrtmann, I. S., Magalhães, C., Hernáez, P., Mantelatto, F.L. (2010). Offspring production in three freshwater crab species (Brachyura: Pseudothelphusidae) from the Amazon region and Central America. Zoologia (Curitiba) 27, 965-972. [CrossRef]

Yeo, D.C.J., Ng, P.K.L., Cumberlidge, N., Magalhaes, C., Daniels, S. R., Campos, M. R. (2008). Global diversity of crabs (Crustacea: Decapoda: Brachyura) in freshwater. Hydrobiologia 595, 275-286. [CrossRef]

Yeo, DCJ., Ng, PKL. (2012). Sodhiana, A new genus of freshwater crab from south Asia (Decapoda: Brachyura: Gecarcinucidae). Raffles Bulletin of Zoology 25, 279-284. 